\title{
Preparation of Northern Mid-Continent Petroleum Atlas
}

\author{
Quarterly Report \\ July 1 - September 31, 1997 \\ By \\ Lee C. Gerhard; Timothy R. Carr; W. Lynn Watney
}

Work Performed Under Contract No.: DE-FG22-97BC15008

\author{
For \\ U.S. Department of Energy \\ Office of Fossil Energy \\ Federal Energy Technology Center \\ P.O. Box 880 \\ Morgantown, West Virginia 26507-0880
}

By

The University of Kansas Center for Research Inc.

Lawrence, Kansas 


\section{Disclaimer}

This report was prepared as an account of work sponsored by an agency of the United States Government. Neither the United States Government nor any agency thereof, nor any of their employees, makes any warranty, express or implied, or assumes any legal liability or responsibility for the accuracy, completeness, or usefulness of any information, apparatus, product, or process disclosed, or represents that its use would not infringe privately owned rights. Reference herein to any specific commercial product, process, or service by trade

name, trademark, manufacturer, or otherwise does not necessarily constitute or imply its endorsement, recommendation, or favoring by the United States Government or any agency thereof. The views and opinions of authors expressed herein do not necessarily state or reflect those of the United States Government or any agency thereof. 
Disclaimer:

This report was prepared as an account of work sponsored by an agency of the United States Government. Neither the United States Government nor any agency thereof, nor any of their employees, makes any warranty, express or implied, or assumes any legal liability or responsibility for the accuracy, completeness, or usefulness of any information, apparatus, product, or process disclosed, or represents that its use would not infringe privately owned rights. Reference herein to any specific commercial product, process, or service by trade name, trademark, manufacturer, or otherwise does not necessarily constitute or imply its endorsement, recommendation, or favoring by the United States Government or any agency thereof. The views and opinions of authors expressed herein do not necessarily state or reflect those of the United States Government or any agency thereof.

\section{TITLE: PREPARATION OF NORTHERN MID-CONTINENT PETROLEUM ATLAS}

Cooperative Agreement No.: $\quad$ DE-FG22-97BC15008--01

Contractor Name and Address: The University of Kansas Center for Research Inc.

Date of Report: December 1, 1997

Award Date: $\quad$ August 12, 1997

Government Award for Current Fiscal Year: \$250,000

Principal Investigators: $\quad$ Lee C Gerhard (Principal Investigator)

Timothy R. Carr (Program Manager)

W. Lynn Watney

Project Manager: $\quad$ Chandra Nautiyal, NPTO, Tulsa

Reporting Period: $\quad$ July 1, 1997 -- September 30,1997

\section{OBJECTIVES}

As proposed, the third year program will continue and expand upon the Kansas elements of the original program, and provide improved on-line access to the prototype atlas. The third year of the program will result in a digital atlas sufficient to provide a permanent improvement in data access to Kansas operators. The ultimate goal of providing an interactive history-matching interface with a regional data base will be demonstrated as the program covers more geographic territory and the data base expands. The atlas will expand to include significant reservoirs representing the major plays in Kansas, and North Dakota.

Primary products of the third year prototype atlas will be on-line accessible digital data bases and technical publications covering two additional petroleum plays in 
Kansas and one in North Dakota. Regional databases will be supplemented with geological field studies of selected fields in each play. Digital imagery, digital mapping, relational data queries, and geographical information systems will be integral to the field studies and regional data sets. Data sets will have relational links to provide opportunity for history-matching, feasibility, and risk analysis tests on contemplated exploration and development projects. The flexible "web-like" design of the atlas provides ready access to data, and technology at a variety of scales from regional, to field, to lease, and finally to the individual well bore. The digital structure of the atlas permits the operator to access comprehensive reservoir data and customize the interpretative products (e.g., maps and cross-sections) to their needs. The atlas will be accessible in digital form on-line using a World-Wide-Web browser as the graphical user interface.

Regional data sets and field studies will be free-standing entities that will be made available on-line through the Internet to users as they are completed. Technology transfer activities will be ongoing from the earliest part of this project, providing data information sets to operators prior to the full digital atlas compilation.

\section{SUMMARY OF TECHNICAL PROGRESS}

As part of the first two years of the project "Pages" and data schema for the atlas overview and field studies were developed and made accessible through the worldwide-web. The atlas structure includes access to geologic, geophysical and production information at levels from the national, to the regional, to the field to the individual well. Several approaches have been developed that provide efficient and flexible screening and search procedures. Database queries are now routed through a relational database management system that provides the individual access to production, welllog, core and other databases. In the third year, this flexible access will be expanded to include access to user defined maps, cross-sections and other technical products. The continually evolving prototype of the digital atlas is accessible through the Kansas Geological Survey Petroleum Research Section (PRS) HomePage (The Universal Resource Locator [URL] is http://www.kgs.ukans.edu/PRS/PRS.html). The Digital Petroleum Atlas (DPA) HomePage is available directly at http://www.kgs.ukans.edu/DPA/dpaHome.html. Technology transfer is underway through presentations at national and regional meetings and through the use of monthly electronic updates and the on-line availability of the DPA products. Project information and Quarterly Progress Reports are linked to the Digital Petroleum Atlas HomePage.

All project personnel are hired. Criteria and procedures, developed as part of the Year 2 Atlas Project, are being used to identify and select two additional plays in Kansas and an additional play in North Dakota. Work is underway to gather the necessary to data in order to make a final play selection.

\section{TECHNOLOGY TRANSFER}

Technology transfer is ongoing through presentations at national and regional meetings and through the use of electronic updates and the on-line availability of the 
DPA products. Project information and Progress Reports are linked to the Digital Petroleum Atlas HomePage. The prototype Digital Petroleum Atlas remains one of the most visited pages on the Kansas Geological Survey web site (Current usage statistics can be accessed at the bottom of the Petroleum Research Section HomePage or at http://www.kgs.ukans.edu/PRS/usage/past stats.html). In a typical 30 day period the DPA is accessed by 7,000 different visitors. Industry continues to access and use the digital data and technology from the DPA project. 